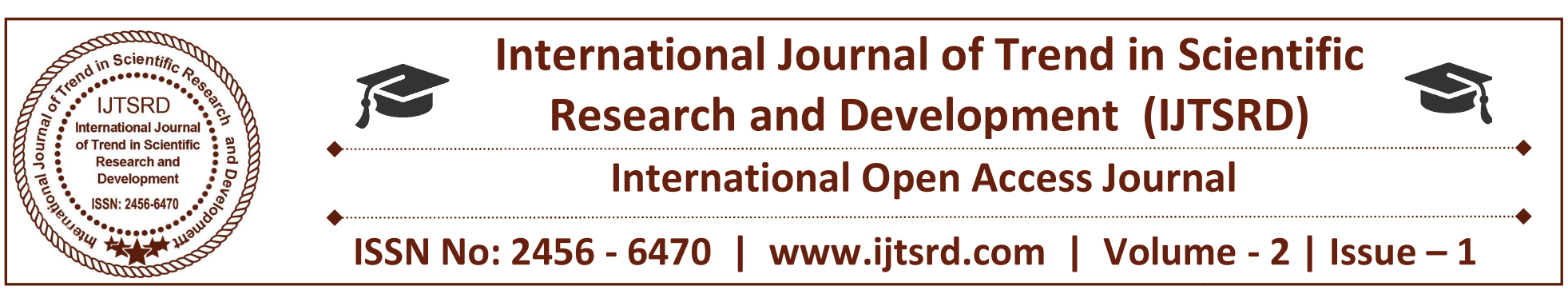

\title{
Role of Panchayats in planning and implementation of Right to Work: A study of MGNREGA in District Budgam in Jammu \& Kashmir
}

\author{
Dr. Gazala Firdoss \\ Lecturer of Persian, Government Degree \\ College Magam, Budgam, Kashmir
}

\section{ABSTRACT}

The Act known as National Rural Employment Guarantee Act (NREGA) created a justifiable "Right to work" for all households in rural India. This Act renamed as the Mahatma Gandhi National Rural Employment Guarantee Scheme (MGNREGS) is an unprecedented intervention by the Government in reforming and reenergizing the (rural) labour market both by way of correcting the prevailing anomalies and in providing livelihood security to millions of rural poor. In conflict-ridden Kashmir's rural areas that are caught in widespread poverty, vulnerability and lack of basic infrastructure, the launching of the NREGA brought a lot of hope and optimism. As in Kashmir society most of the rural poor are largely dependent on the prospects of agriculture sector which is facing the problems of productivity in absolute and relative terms in contemporary times because of climatic and other environmental and socio-cultural concerns. Thus the promised 100 days of guaranteed wage employment per household per annum at the stipulated minimum wages has not only reduced the rampant under and unemployment in Kashmir's rural areas, but also impacted the stagnant wage structure for the rural unskilled workers. MGNREGA is also a glaring example which has ensured community participation in planning, implementation, monitoring and evaluation (Social Audit). It also aims at enabling the local bodies to move towards good governance through the transparency, accountability and participatory mechanisms. Even the efficacy of the institutional performance and active participation of the community determine the overall effectiveness of
NREGS. However, after more than half a decade of policy implementation the only major available information source about the state - the "Government official figures" - do not show a healthy picture when compared to other parts of India and generate a lot of questions and ambiguity, addressing the dearth of ground level literature, which could have explained the myths and realities behind the fluctuating and comparatively low performing official estimates. This paper is a modest attempt in this direction to highlight the feasibility and contextual dilemmas of the MGNREGA in Kashmir with an empirical study of one of the most backward Districts of the Valley i.e. District Budgam. It also analyses the official figures and their limitations and provides field reflections on some of the limitations in the proper implementation of the scheme. In addition to this it highlights the issues and challenges in the smooth functioning of the Panchayat Raj Institutions in the proper implementation of the scheme. The study has been carried out with a proper scientific methodology, and to elicit the relevant information the researchers have employed non participant observation and interviews with the stakeholders as key research methods. In summation from this study policy conclusions can be drawn based on a general analysis of the set-up, past experience and the findings from the field study.

\section{Introduction:}

Since independence, the government of India launched a number of poverty alleviation and employment generation programmes, especially for rural people, like TRYSEM, IRDP, RLEGP, JRY, 
NRY, SGSY, etc. These programmes were somehow effective, but not up to the expectations of the people in solving the problem of unemployment and poverty eradication on account of several shortcomings noticed in the wage employment programmes. Most of the shortcomings in these programmes and their failure were likely to be: lack of awareness, lack of sincerity, lack of community participation, lack of complete awareness, lack of planning, Panchayats not well equipped, Quality of assets created not always of requisite standard, Reports of false muster rolls, Problems in payment (often less than prescribed wages and disparity between wages paid to women and men, Contractors persisted, Diversion of funds), Weak monitoring and verification systems, Lack of comprehensive data base, Inadequate capacity of implementing agencies, Multiple wages employment programmes running in parallel. Lack of Genuine will to decentralize, Lack of organization of the poor for greater participation, and Lack of Public Accountability. Considering these deficiencies in the earlier programmes, MGNREGA was designed and given a legal status (Goel \& Rajneesh, 2009: 369). The MGNREGA is a step towards the right to work, as an aspect of the fundamental right to live with dignity.

The Article 39(A) and 41 of the Indian constitution declare:

"The state shall ........direct the policy towards securing, that the citizen: men and women equally, have the right to an adequate means of livelihood......" (Article 39 A).

"The State shall ...........make effective provision for securing the right to work" (Article 41).

India, in the light of the constitution, enacted the employment guarantee act first ever in the world and assured at least 100 days guaranteed employment for the rural people. The Mahatma Gandhi National Rural Employment Guarantee Act, 2005, States:

"An Act to provide for the enhancement of livelihood security of the households in rural areas of the country by providing at least one hundred days of guaranteed wage employment in every financial year to every household whose adult members volunteer to do unskilled manual work and for matters connected therewith or incidental there to (The Gazette of India, 2005: 48)."
Thus the National Rural Employment Guarantee Act (NREGA), presently known as Mahatma Gandhi National Rural Employment Guarantee Act, is an unprecedented intervention by the Government in reforming and reenergizing the (rural) labour market both by way of correcting the prevailing anomalies and in providing livelihood security to millions of rural poor. Most of the rural poor are largely dependent on the prospects of agriculture sector which is facing the problems of productivity in absolute and relative terms. The promised 100 days of guaranteed wage employment per household per annum at the stipulated minimum wages has not only reduced the rampant under and unemployment in rural areas, but also impacted the stagnant wage structure for the rural unskilled workers.

The rights based NREGS emphasizes on community participation in planning, implementation, monitoring and evaluation (Social Audit) of the programme. It also aims at enabling the local bodies to move towards good governance through the transparency and accountability mechanisms. Elaborate institutional arrangements have to be made to realize not only the objectives of the NREGA but also to make the formal (PRIs) and informal institutions vibrant. Thus, the efficacy of the institutional performance and active participation of the community determine the overall effectiveness of NREGS.

In Jammu and Kashmir (J\&K) nearly $80 \%$ of the population is still dependent on agriculture and allied activities for its livelihood (GoJK 2014). Rural J\&K hosts more than $70 \%$ of the total population, out of which $26.14 \%$ is below the poverty line (BPL), which in average terms means that out of every four persons, one belongs to the BPL category (JKDES 2008). Around the time that the MGNREGA was enacted, rural unemployment in the state stood at $4.7 \%$, which was double the $2.4 \%$ of the all- India figure (NSSO 2008) and it was expected to increase owing to the "consistent decrease in landholding size and factor productivity" (MoA 2014). Hence, there was an obvious need of a MGNREGA type initiative to protect not only the current but also the expected future vulnerabilities by providing employment and thereby maintaining their subsistence level. In addition to livelihood protection, it was also seen as an opportunity to revitalize the old and create new basic rural infrastructure in order to boost the rural economy. 
Recognizing this need, the policy was extended to three backward districts in initial phase (Doda, Kupwara and Poonch) during the first phase in 2006, which was later extended to two more districts (Anantnag and Jammu) during the second phase and finally to the entire state during the third phase in 2008-09. However, beyond the "complex state-centre relationship within which policy is inherently caught" (Dreze and Khera 2011: 74), it also got caught in some serious state specific complexities, which did not allow it to have a smooth landing.

Although the policy was extended to the state in 2006, the National Rural Employment Guarantee Act (NREGA) was not in place until April 2007. This was because of the state's special constitutional status under Article 370, which does not allow the direct extension of any central Act, unless asked for and approved by the state government. Until April 2007 when the Act was formally extended to the state, the implementation was carried out under the Rural Employment Guarantee Scheme (Alam et al 2010). After the extension of the Act when it came to the formulation of J\&K Rural Employment Guarantee Scheme (JKREGS), a further set of administrative and institutional complexities arose. The architecture of MGNREGA as a central strategy is deeply rooted in the 73rd constitutional amendment (73rd CA). However, in J\&K Panchayat institutions are governed by the J\&K Panchayati Raj Act 1989. While this Act incorporated a three-tier institutional system with administrative rules that kept changing over time, it did not guarantee the same level of powers to these institutions as granted by the 73rd constitutional Amendment Act. More importantly, when the JKREGS was formulated no such institutions were in place due to the conflict and disturbances in the region. Hence, the state was forced to opt for an alternative and relatively weak institutional strategy to implement the MGNREGA. At the Village level a three member deh majlis was to be nominated for planning and execution, at the block level, the block development council was to be constituted with members from the deh majlis and line department, and at the district level the district development board was to be constituted. With the formulation of the JKREGS, the State Employment Guarantee Council (SEGC) was also constituted in August 2007 (Alam et al 2010). Nonetheless, a further restructuring took place with the election of the first tier of the Panchayats in 2011. Though not visible in the official data, overall these dilemmas created differences between the normatively envisioned and the actual institutional process of the MGNREGA in the state, and also affected ground level implementation and outcomes.

\section{Methodology:}

This study stands for a scientific and empirical study of MGNREGA in contemporary Kashmir society. The study essentially applied qualitative techniques in order to gain a deeper understanding of the role of Panchayats in planning and implementation of right to work in the state. The study also involved collecting information from NREGA workers, administrators, contractors and others stakeholders especially Panchayat raj members. In order to gain a deeper understanding of the problem in question in this qualitative research methodology, case study design has been employed, Supplemented with interviews (structured/open ended questions with workers and gram sabha members), focus group discussions with Panchayat raj members and infrastructural observations. As district Budgam is one of the most backward district of J\&K state, so the remotest area of block khansahib in district was chosen purposively to gain an understanding of the challenges faced by the people who live on margins. Ten villages in remote areas of Block khansahib in district Budgam were studied on case to case basis to draw the relevant inferences during the period of March 2014 to March 2015. The villages surveyed were Ringzabal, Kharian, Zagoo, Chill, Brass, Mujipathri, Basant-weder, Dragadh, Katchwari, and Balpora.

\section{Experiences from field}

\section{Awareness on MGNREGA}

The MGNREGA guidelines provide for a greater emphasis on awareness generation through Information, Education and Communication (IEC) exercise to publicize the key provisions of MGNREGA and its various processes like registration, demanding employment, unemployment allowance, grievance redressal and social audit. The officials claimed that the strategy adopted for building awareness about MGNREGA included conferences, workshops, seminars, and training programmes, besides use of electronic and print media to make people aware of the strengths of MGNREGA. The officials too informed that the local institutions were involved in the implementation of the Scheme through meetings and different IEC activities. Contrary to field observations, the officials reported 
that people were made aware of the minimum/ additional wages through awareness camps and village level meetings. However, the effectiveness of these measures is not visible at the operational level as people still seem ignorant about the Scheme and the rights and entitlements of the workers in these villages. Consequently, it can be concluded that this component has not been properly addressed to. In the absence of the complete structure of PRIs in the State it is becoming increasingly difficult for the administrative machinery to educate people about the scheme. Since the major target of the programme is Panchayat raj members so that they will subsequently disseminate awareness to potential wage seekers, rural households, and pay special attention to the deprived and marginal communities. During this study only $60 \%$ respondents were aware on their right to demand 100 days of employment, when in 'need'. Panchayat members at village level held that this is because of non existence of PRIs in the state at block and district levels.

\section{Awareness on provision of acknowledgement receipt}

A written application seeking work is to be made to the gram Panchayat or Block Office, stating the time and duration for which work is sought. The GP issues a dated receipt of the written application for employment, against which the guarantee of providing employment within 15 days operates. In all of the villages studied, none of the wage seekers were aware that an acknowledgement receipt will be provided if they demand work. It is because there is no check on the village level Panchayat members because of the absence of institutional structure at Block and District levels.

\section{Awareness on entitlement for unemployment allowance}

Under MGNREGA, if employment is not provided within 15 days of demand, daily unemployment allowance in cash is to be paid. The States are liable to pay unemployment allowances in all such cases. During the study we have assessed the awareness level amongst the wage seekers on entitlement for unemployment allowance. In all the villages studied none of the wage seekers were aware of their entitlement for unemployment allowance. Common people held that an institutional PRI structure at Block and District level if in place would have acted as a pressure group, demanded these entitlements from respective authorities and subsequently disbursed to the deserved populace.

\section{Job Cards}

Any household willing to seek work under MGNREGA has to get itself registered and have a job card issued by the Gram Panchayat/Local village body. During this study in all the villages all the willing households have not been issued job cards. 24 household respondents revealed that the job cards are being issued on the basis of favouritism and nepotism and even in some cases to undeserved households. These respondents believed that a complete institutional structure would have ensured check and balance and transparency in the system. Guidelines also stipulate that photographs of all adult members have to be affixed to the job card, but in most of the cases job cards verified did not have photographs of the adult members of the household.

\section{Demand for Work}

Any registered household can demand work by submitting an application for work and the PRI is required to provide an acknowledgment receipt. The PRIs are required to start work from the approved shelf of works on receipt of demand for employment. In all the villages studied none of the interviewed workers reported that they apply for job when in 'need'. They held that the decision to start work was being taken only on the basis of orders from District/block offices. This inconsistency and lack of democracy in the demand for work is because of absence of institutional structure of PRIs at Block and District levels in the state.

\section{Preparation of Labour Budget and Shelf of Works}

In order to make a prior assessment of the quantum of demand of employment and its timing, a labour budget is to be prepared according to guidelines. The labour budget is supposed to be presented by the Gram Panchayat for approval of Gram Sabha also ensuring that all sections are adequately represented in the meeting. In none of the studied villages Gram Sabha meetings were conducted for approval of labour budget. So none of the visited villages have development plan and shelf of works discussed and finalized in the Gram Sabha. This is because of weak institutional structure of PRIs in the state. 
Employment provided and Unemployment Allowance

According to the Act, an adult member of any rural household (willing to do unskilled work) who demands work should be provided employment within 15 days of demand. During this study it was reported that none of the wage seekers are provided employment within 15 days of demand. Workers in these villages have reported that work has not been provided even after making the demand.

If an applicant for employment under the scheme is not provided employment within 15 days from the date on which the employment has been sought, he/she is entitled to a daily unemployment allowance. Workers during the study reported that in the visited villages no unemployment allowance was paid to anyone.

\section{Payment of Wages}

Wages are paid as per Government of India (GoI) notified MGNREGA wage rates for each State and to ensure timely payment and prevent misappropriations, the GoI mandated that payments be made through bank and post office accounts of beneficiaries. All the respondents reported that all of MGNREGA payments in the State are made through banks. It is also evident that the provision of entitlement for minimum wages has not been complied in all the cases in the State, in sampled villages we have found instances of workers being paid less than minimum wage rates.

Timely payment of wages is another concern, in most of the cases payment is delayed for months and in some cases even for years together, which can be assessed by the famous sayings of these workers that: NREGA.... Marega tab Paisa Taregaa (means get money after death).

The low minimum wage of Rs. 150 per day in a labour-scarce State like J\&K has been the key factor responsible for weak response from the local job seekers as the market wage for most of the time ranges between Rs. 400- 500 per day for similar works.

\section{Use of Machinery \& Involvement of Contractor}

The MGNREGA prohibits the use of contractors for work and machinery to ensure that the labour is not exploited and benefits and wage payments are provided directly to the workers. Some incidents, regarding use of labour displacing machinery have been observed in the visited village of Ringzabal and Chill. Involvement of contractor is also reported in many of the villages studied, and in most cases panchs and sarpanchs have acted as contractors rather than peoples representatives.

\section{Wage Material ratio}

In the entire sample villages 60:40 wage material ratios were not being maintained at GP level. Wage material ratios were maintained only in the sampled villages of Mujpathri. Common people held that an institutional and transparent complete structure of PRIs would have ensured an optimum wage material ratio.

\section{Social Audit}

MGNREGA has inbuilt transparency and accountability mechanism in its design viz. pro-active disclosure and social audits. For an effective social audit process it is imperative that the PRI members are aware of the processes and procedures as provided in the act. As per our assessment only in one village of Mujipathri the PRI members were 'fully aware' on social audit processes and procedures. In villages of Chill, Brass, Dragadh, Katchwari and Balpora we found them aware 'only to some extent' and in Kharian, Ringzabal, Zagoo and Basant-weder villages 'not at all'.

\section{Lack of Coordination}

During the study respondents held that; in the absence of Panchayati Raj Institutions in the State because of pending PRI elections (at Block and District level), an adhoc arrangement is in place for the planning and implementation of the Scheme. The alternative mechanism of a three-member committee nominated by the Gram Sabha at the Panchayat level with secretarial assistance of the former Panchayat Secretary seems inherently inconsistent with the basic spirit of the Scheme, and this type of structure has least coordination among the three tiers.

\section{Suggestions:}

Community participation is a vital feature of the Scheme which will help bringing greater transparency in the entire planning and implementation process and making the delivery system accountable to the community. Gram Sabhas and PRIs have to play a key role in the 
planning, selection of works, monitoring and Social Audit. There is a need to institutionalize the role of the community. In this context, government can play a significant role by holding the elections for other two tiers of Panchayat in the state.

Though under MGNREGA, the State is empowered to recruit a number of functionaries such as field assistants and mates, the existing staff is inadequate to meet the demands of the Scheme both at the planning stage and in its implementation. Action should be taken to recruit staff proposed under the Scheme at the earliest.

$>$ Due to lack of awareness, the workers were not provided with the mandatory facilities at worksite. There is a need to educate the Village Committees and Gram sabha about these entitlements of the workers under the Act and provide funds to meet the same.

Maintenance and updating of job cards is another area which merits special mention. The posting of Gram Rozgar Sevaks would help updating the entries in the job cards regularly.

$>$ Participation of local workers was found to be minimal because of the significant difference between the market wage and minimum wage. There is a need to re-examine the minimum wage issue.

As provided in the Act, there should be a full-time Programme Officer responsible for the administration of the Scheme in the State. Instead, the Block Development Officer has been designated as the Programme officer, who is unable to dedicate full time to the Scheme.

\section{CONCLUSION}

In a conflict ridden region where poverty and vulnerability is widespread and the basic infrastructure is very poor across the rural areas, the MGNREGA has an instrumental protective and promotive role in both reducing poverty and vulnerability, and in setting the rural economy on a sound and sustainable footing. The new state government in J\&K needs to show its political and administrative commitment on various fronts. This includes conducting the election of the other two tiers of the Panchayats and full power disbursement to them so that they can function properly. Second, an adequate bureaucratic staff (GRS, programme officers and village level workers) needs to be appointed while enhancing the capacity building of both the bureaucratic and non-bureaucratic staff which lies at the heart of bringing policy to people as a legal entitlement rather than a conventional government scheme. Third, gender balance in the local bureaucratic staff and in PRIs needs attention. This is necessary because women here are not very comfortable in talking to or working with men who do not belong to their household. Fourth, extensive application of the MGNREGS's provision of establishing partnership with the line departments in order to strengthen the quality of assets by availing their technical, monitoring and financial support, and ensure maximum community participation in order to make the MGNREGA a real bottom-up, transparent, inclusive and equitable policy. Finally, while there are limited options for employment generation during the lean winter period in Kashmir because of prevailing climatic conditions providing steady employment immediately before and after winter will be very helpful, considering that the external job market, especially agriculture, remains down during this period. This will mainly help those who have variable income and are prone to seasonal shocks.

\section{REFERENCES:}

1. Alam S, G Dar and R Sharma. (2010). Planning and Implementation of National Rural Employment Guarantee Scheme in Jammu and Kashmir: A Process Study, National Institute of Rural Development. Hyderabad.

2. Basu, D.D. (2009). Constitutional Law of India, Lexis Nexis Butter Worths.

3. Dreze, J and R Khera (2011). "The Battle for Employment Guarantee" in R Khera (ed.), the Battle for Employment Guarantee. Oxford University Press. New Delhi.

4. Goel, S.L. and Rajneesh, Shalini (2009), Panchaayati Raj in India: Theory and Practice, Deep and Deep Publication, (P) Ltd. New Delhi.

5. GoJK. (2014). "Department of Agriculture, Kashmir Division", viewed online on 19 July 2014, http:// www.diragrikmr.nic.in/

6. JKDES. (2008). "Below Poverty Line (BPL) Survey 2008 J\&K State", J\&K Government, Directorate of Economics and Statistics Planning 
and Development Department. Jammu and Kashmir.

7. Malla, Mushtaq A. (2014). NREGA in Kashmir opportunity for derailed social protection. Economic and political weekly December 27, 2014 vol xlix no. 52.

8. MoA. (2014). "Agricultural Census (2010-11)", Governent of India, Agriculture Census Division Department of Agriculture and Co-operation, Ministry of Agriculture.

9. NSSO. (2008). "Employment and Unemployment Situation in India 2005-06 (NSS 62nd Round, July 2005-June 2006)", National Sample Survey Organization, Ministry of Statistics and Programme Implementation. Government of India. New Delhi.

10. The Gazette of India. (2005). "The National Rural Employment Guarantee Act, 2005”, Ministry of Law and Justice, (Sept. 7), No.48. 